\title{
Representation of Places in Etel Adnan's In the Heart of the Heart of Another Country and Of Cities \& Women (Letters to Fawwaz)
}

\author{
LAURE ZARIF KEYROUZ
}

\begin{abstract}
This article will take a close look at two books of Etel Adnan which are strongly tied to the representation of places. References to nature found in both books link the places she is physically present in to her inner-spaces. Additionally, the people she encounters in these locations also become elements with which she weaves different places together. In Of Cities \& Women (Letters to Fawwaz), the notion of place is particularly enriched by the different qualities of the women she finds in each location, comparing the situation of women in the Orient and the Occident. The shadow of recent wars hangs heavy in the memories of Adnan as she travels between these different places in both books - the thought of which never abandons her.
\end{abstract}

Keywords: places; maps; literature; art; symbols; nature; woman; war

\section{Introduction}

Etel Adnan is one of Lebanon's most important contemporary writers and a prime example of the intellectual nomadism ${ }^{1}$ that defines much of Lebanese contemporary literature and art. Her tangled personal journey across several continents have found their way into every aspect of her writing, which documents not only her travels but also her emotions and ever-changing perspectives as seen through the lenses of the places and spaces she finds

\footnotetext{
Etel Adnan, a great nomad, has ventured to many places throughout her long life. Born in Beirut in 1925, she travelled from Lebanon to study Philosophy at the Sorbonne in Paris. Later on, in 1955, she moved to the United States - to study philosophy at Berkeley University, California - where she stayed for 20 years. Her work then brought her back to California to teach Philosophy and Arts at San Rafael Dominican College, finally returning to Lebanon in 1972 to work as a journalist in Beirut. There she experienced the first dramatic years of the civil war. Because of the turmoil, she returned to Paris and later to California. To this day, she continues travelling and discovering new places, mountains and seas. In addition to her vast literary production, she is a visual artist, working with painting on canvas, tapestry and artist books. Using metaphor, Adnan transforms some traditional natural landscapes (i.e. sea and mountains) and urban landscapes (i.e. cities) into new interior spaces and memories of real life.
} 
Representation of Places in Etel Adnan's In the Heart of the Heart of Another Country

herself in. This article ${ }^{2}$ is primarily concerned with two questions: Where does the literature of Adnan take place, and why does it take place there? What is the connection between places and spaces mainly in the literature and art of Adnan?

Through comparative methodology, these two questions will be addressed using selections from her books In the Heart of the Heart of Another Country and Of Cities and of Women (Letters to Fawwaz).

In order to understand the history of a location, it is important that both the space and the place - which will be further defined in the first part of this paper - of it are intertwined. "Place" refers to the concrete aspect of a location, while "space" incorporates its abstract elements. Each of these is rendered unique through individual experiences. With the rise in importance of maps as narratives there has been a growing awareness of the geographies of literature. A clear distinction has made between spaces and places" ("space is abstract and place is concrete") and are made unique by the personality and experience of those who have visited them, even for a short period of time (Yales 2015: 9). The terminology of "representation of places" and symbols ${ }^{4}$ will be applied and interlaced with the comparative literary reading (by examining the content and theme, along with their structure) of the two books by Adnan. Using words, the author locates herself within one book but is constantly moving between different places. Adnan comes originally from a diverse family, with a legacy of nomadism 5 (Adnan 1996: 1-2).

Her own personal story also took her on numerous journeys. She moved to Paris and then to California for study and work, only to move -17 years

2 I would like to thank my advisor Aleš Vaupotič, co-editors Janetta Ledell and Samantha Liverani.

3 Rachel Yales quotes John A. Agnew as seeing place "as having two key meanings: "absolute" geometric location or "node" in space and the knowledge that a location in space has unique, distinctive properties which affect what happens there." (Yales 2015: 9) She later references Moretti's definition of maps as being "analytical tools: that dissect the text in an unusual way, bringing to light relations that would otherwise remain hidden." (Yales 2015: 22)

4 In this article, the words in italics are used because they are coined, studied by many authors and essential in the work of Adnan.

5 "My mother was a Greek from Smyrna, when Smyrna, before World War I, was a predominantly Greek city, a Greek speaking community within the Ottoman Empire. My father was an Arab. He was born in Damascus, Syria. At the age of twelve he joined the Military Academy in Istanbul, called the War College. That was close to the end of the nineteenth century. Damascus was a part of the Ottoman Empire, and my father was an Ottoman officer [...] I was born in Beirut, Lebanon, because at the end of World War I my parents left Turkey and came to settle in Beirut. Beirut was close to Damascus, my father's home [...]" (Adnan 1996: 1-2) 
later - back to Lebanon to become an editor for two major newspapers. When civil war broke out, she was forced to flee - first to Paris, and then once again to California, where she published many books and gained worldwide acknowledgement as a writer and painter.

This nomadic movement ${ }^{6}$ is a key aspect of her writing, in which she weaves her location with her experiences, impressions, and cultural reflections, to create a virtual mind-map of her own personal story.

\section{Definitions of Representation, Topography and Maps}

In order to discuss the various aspects of Etel Adnan's work as a mind-map, a few definitions are required: representation of places, topography, and maps.

First, the historian Chartier (2014) defines representation ${ }^{7}$ as " [...] an image that brings to mind and memory an absent object, and which paints them as they are [...] To represent is to convey something indirectly through words and gestures, figures and signs: enigmas, emblems, fables, and allegories”. It refers to the ability of an author to recall a place or a person that is not physically present at the time through his or her text, or by an artist through his or her work (painting, sculpture, etc.).

Second, the definition of places is also of key importance in the literature of Etel Adnan. The concept of the turn regarding places must be understood in order to map her narratives.

A distinction must be made between geographical (mountains, landscapes, physical and political barriers) and literary places. Literary places are used by writers to convey the place and time they want the reader to be in. The use of places in literature has the power to stimulate the reader's emotions and senses by choosing carefully the type of setting, which may evoke the sentiments and sensations that the author wishes to underline (Jeremiah 2000: 23-25). Throughout her writing, Adnan defines 'place' through capturing the moment, as one might find in impressionist paintings. She has been influenced by many great artists, including Picasso, Cézanne, and others. "Picasso managed to define a place, to capture the spirit that invests a site, and which comes from a mixture of culture and geography, the one never without the other" (Adnan 1993: 7).

6 I have previously discussed the issue of mobility and identity in the art and literature of Etel Adnan (see Zarif Keyrouz 2020).

7 The Dictionary of the French Language (Dictionnaire de la langue française) was published by Furetière in 1960 . 
Representation of Places in Etel Adnan's In the Heart of the Heart of Another Country

As Bonniot-Mirloup states that "literary works, like other art works, have the power to convey an imaginary of places, and when shared, to become part of the collective memory" (Bonniot-Mirloup 2016: 2). Places help the reader follow ideas and ideals laid out for them, as they are drawn into the imagery of the places described. Adnan's writing consistently provides a clear path for the reader to immerse themselves in places as they travel with her along her physical, emotional, and cultural journey.

The term topography is mentioned in an article of Ernest W. B. Hess-Lüttich ("Spatial Turn: On the Concept of Space in Cultural Geography and Literary Theory"):

It no longer merely involves place descriptions, [...] but also the art of "mapping", [...] according to the American literary critic Hillis Miller, the question emerges as to how topographical descriptions work in poems, novels or philosophical texts. [...] It is language that creates facts here: "The topography of a place is not something there already, waiting to be described, constatively. It is made, performatively, by word or other signs, for example, by a song or a poem" (Hess-Lüttich 2012: 7).

Adnan exemplifies this kind of creation of topography, describing the events, feelings and ideas that come to her as she experiences each location. Each place inspires her to recreate it for the reader through her words and imagery, cultivating new relationships and connections between the geographical aspects of each place as well as the metaphorical, symbolic, and cultural concepts which she encounters there.

Today, through the use of modern digital maps (i.e. Google maps), readers can trace the author's movement within a book using the texts as guide ${ }^{8}$. While maps can be used to trace the movements of the protagonist throughout Adnan's books, she also uses them symbolically within the text to underline connections within her own life. Adnan has always had a passion for maps, and bought them whenever she could, in the hope of understanding the geography of her family and, with it, her history. In the first book, In the Heart of the Heart of Another Country, she finds herself buying maps and looking at a flat image of Turkey. Sitting in front of a large window that allows her to see the whole

8 Using new media technologies to document and graphically visualize the different places, these locations indicated in the text of Adnan can be used to construct trajectories diagrams of the places in the literature using nodes and lines. Nodes are the points of the different locations, and lines are the links which visually represent her movement between all of the places. 
of Mount Tamalpais, her finger searches for Greek Smyrna (the birthplace of her mother) (Adnan 2005: 74). She continues later: "I'll buy some other map tomorrow: I'll have to anchor myself, somewhere in deep water, [...]” (ibid. 75).

In order to understand Adnan's memories of her past, as well as her current perspective, an attempt at mapping places in her books will provide a more complete picture for her readers of her experiences and ideas. The concepts of heterotopia and "literary psychogeography" in the wanderings of Adnan are also vital to the understanding of her writings, as her discussions constantly intertwine the reality of her actual location with past memories and trauma, personal reflections, moods, and feelings. Adnan is finding new "places" as these locations become imbued with new functions and symbolic significance for her.

\section{Heterotopia and Juxtaposition of Places for Etel Adnan}

Many $20^{\text {th }}$-century philosophers ${ }^{9}$ have discussed the notion of places and its relationship to and differences from space. For Michel Foucault, places take on a functional and symbolic role, which over time are preserved. Heterotopia, is a term coined by Foucault in his 1967 lecture, (Des Espaces Autres ${ }^{10}$ ), Of Other Spaces: Utopias and Heterotopias. In contrast to Utopia, which "are sites with no real place", heterotopia are "places that do exist and that are formed in the very founding of society" (Foucault 1984: 3) With “[...] heterotopias, there might be a sort of mixed, joint experience, which would be the mirror" [...] "as a sort of simultaneously mythic and real contestation of the space in which we live, this description could be called heterotopology" (ibid. 4). "The heterotopia is capable of juxtaposing in a single real place several spaces, several sites that are in themselves incompatible" (ibid. 6).

In connection to this concept of heterotopia, - the concrete and social "real" locations of Foucault but removed from the outside reality, Adnan comments upon Spain in Of Cities and Women (Letters to Fawwaz): "Spain has been a mirror for me. An enormous mirror in which my reflection is but a small fragment." (Adnan 1993: 56). As if it were a microcosm to which Adnan can see her reflection and the reflection of "a lot of people in this mirror: people of

9 The name of many important philosophers is summarized "relying on space, time or history": "Among them are Ernst Cassirer, Gilles Deleuze, Gaston Bachelard, Augustin Berque and many others." (Rousseaux 2009: 3)

10 Translated from the French by Jay Miskowiec, in October 1984, from Architecture/ Mouvement Continuité. 
Representation of Places in Etel Adnan's In the Heart of the Heart of Another Country

yesterday and people of today, women, men, children, animals, plants" (ibid. 56). Thus, Spain is a real location, which she as a nomad enters in as an outside observer. But, on the other hand, Adnan is a citizen of this world - the mirror of herself, which is also a symbolic reflection of her complex and multifaced life.

\section{Literary Psychogeography in the Wanderings of Adnan}

In his Introduction to a Critique of Urban Geography, Debord (1955: 23) defines psychogeography as, "the study of the precise laws and specific effects of the geographical environment, whether consciously organized or not, on the emotions and behaviour of individuals."

In the literature and art of Etel Adnan we can find similarities to Guy Debord's concept of "Literary psychogeography" as outlined by Tjebbe van Tijen " [...] it enables people to wander freely through space and times with eyes and ears / looking and listening" (Shaw \& Van Tijen 1991). Psychogeography was defined by Guy Debord as "the study of the precise laws and specific effects of the geographical environment, consciously organized or not, on the emotions and behavior of individuals" (Debord 1958). Adnan's experience of war has pushed her along a path, which was not completely intentional. As the writings in these two books underline, throughout her life she has succumbed to the forces around her (war, nomadism, isolation, immigration), which at first she experiences and then re elaborates through her reflections on this past within the context of different urban realities. Each of these locations acts as a catalyst for her ideas and reactions, as her past mixes with her geographical present. In fact, Etel Adnan's way of wandering through a city and narrative style take the reader on a journey through time and space as she pieces together the shattered images of her past, including her memories of growing up in Lebanon, the civil war and her constant quest for knowledge. We travel with Adnan in Of Cities and of Women (Letters to Fawwaz) through the "narrow streets" of Barcelona, which she described as claustrophobic (Adnan 1993: 1).

Likewise, chapter 6 of In the Heart of the Heart of Another Country, "Time, Desire, and Fog”, describes Adnan's emotional return to Beirut, Lebanon: "I ended up in $\mathrm{B}[\ldots]$, another wilderness. The wilderness - and the wildness were in my soul" (Adnan 2005: 83). Her return to her homeland allowed her to rediscover the beauty and the history of places she had left so many years before.

In psychogeography literature, spaces are reconstructed through the emotions generated by the descriptions and anecdotes of the narrator and are made available to the reader through his or her experience of the past and 
present. Psychogeography is the exploration of the psychological effects of an urban environment, and here the reader clearly sees how Adnan conveys place through the lens of her own emotions, "we wander for a while [...] we re-enter the city and spend the night walking" (ibid. 43).

\section{Places in of Cities and Women (Letters to Fawwaz) and In the Heart of the Heart of Another Country}

One type of representations of places is Lotman's notion of semiosphere, where boundaries have become "crossroads of culture" and "a zone of semiotic polyglotism, which both separates and unites” (Škulj 2004: 26-27). Unlike Lotman's semiosphere theory - in which he describes a cultural-semiotic system as a totality, but one can live outside of literature -, Adnan lives as if interacting directly with her literature; in In the Heart of the Heart of Another Country she forces the reader to jump quickly back and forth from one piece of information to another ${ }^{11}$, similar to when one scrolls through pages on the internet, skimming to find information, only in search of what we are looking for. Adnan uses the power of this style to capture the attention of the reader with quick, short pieces, mimicking the fast chatting people currently do on digital platforms. The mind becomes distracted and confused because it starts one thing, only to become sidetracked by many other distractions, and later returns repetitively to the same topic over and over again.

In the book Of Cities \& Women (Letters to Fawwaz), on the other hand, the narrative is in the form of a literary psychogeographic "cultural guide" as the protagonist (Adnan) moves between different locations. ${ }^{12}$ It has a slower pace and outwardly takes the form of traditional letter writing. It is divided into nine letters, all dealing with the conditions of feminism. However, although

11 Adnan in In the Heart of the Heart of Another Country was inspired by another book written by William $\mathrm{H}$. Gass with the same title, it is a collection of short stories depicting the state of American Midwest. She claims in the introduction that this book "engages the reader immediately with a series of paragraphs, or sections, each with a heading that sometimes recurs, but often does not. It made a powerful impression on me." (Adnan 2005: xi). Similar to William H. Gass's, Adnan divides her memories into a sequence of repetitive sections in the form of paragraphs: place, weather, my house, a person, wires, the church, my house, politics, people, vital data, education, business, my house, this place and body, the same person.

12 The actual physical locations of the author in Of Cities and Women (Letters to Fawwaz) are: Barcelona, Aix-en-Provence, Skopelos, Murcia, Amsterdam, Berlin, Beirut, Rome and Beirut. 
Representation of Places in Etel Adnan's In the Heart of the Heart of Another Country

physically present in one location, she returns to other places in her mind, recalling other memories, and creating a sort of Heterotopia in each. Although physically present, she is an outsider to the places she finds herself in. She constantly dives into the microcosms of each location, reflecting upon them as an outsider looking in. Symbols of death and rebirth and a strong co-existence of the mountains and the sea are frequently underlined by Adnan, as she travels between and is inspired by the landscapes of Lebanon, America and France.

\section{The Trilogy of Nature, Women and War}

The location of places mentioned is imperative in discussing notions of nature, women and war in Adnan's work. This trilogy creates a mind map for the reader to follow as they journey with Adnan along her travels. Inspired by the landscapes of Lebanon, America and France, symbols of death and rebirth and a strong co-existence of the mountains and the sea are frequently underlined by Adnan. While the three themes are closely linked together, they can also exist on their own, thus creating maps within a map of spaces within places. The reader is left free to follow his or her own trail, creating new places and spaces each time he or she ventures into the book. Aside from the obvious geographical journeys between nations and cities, one may follow her along the paths of women as they seek liberation from societal constraints and sexual exploitation in various contexts and cultures, or from the psychologically destructive civil war to the spiritually liberating natural surroundings. One can even follow her as she travels between houses and hotels, reflecting on the importance of a sense of home or lack thereof. One can even travel with her from the past to the present, or from the culture of the West to the culture of the East. Any of these paths is possible, depending on the map which the reader decides to trace for themselves.

\section{Nature: (Mountains, Sea and Oceans)}

From California, to Beirut, Damascus, to France, nature, weather and landscape change and accompany Adnan through her travels. Adnan constantly refers to nature as a guide and a source of comfort and stability for her across lands.

In the fifth chapter of the book In the Heart of the Heart of Another Country entitled "Present Time," there is a return in the subtitle place to the forest and the "Cork oaks", which seem to reach out to the author as if to embrace her. 
After a brief rest to drink, she continues her wanderings (Adnan 2005: 67). She lets the stars guide her through the wilderness of the Californian desert (ibid. 71). Nature seems to lead her through along her wanderings, providing comfort and nourishment, almost as a mother would. In the positive sense, nature guides her along, as mountains and seas calm her thoughts. In contrast, she mentions the grey and obscure wires, and stark, cold images of cities and wars which seem to cover and constrict nature, and along with it, her own emotional state; "[...] it's the wires that cross my immediate horizon. I have to accommodate my vision, see through them." (Ibid. 22)

In the second letter of Of Cities and Women (Letters to Fawwaz), located in Aix-en-Provence, Adnan recalls the nature symbols of the forests of Lebanon, the myth of Gilgamesh and the Sainte-Victoire Mountain. The forests of Lebanon are connected to her origins and culture. She compares the demise of the forests to the rapid rate of disappearing 'concepts', giving an example from the epic poem of Gilgamesh, “[...] when Gilgamesh kills the god of the Forest of Lebanon. Gilgamesh will die as a consequence of this, having lost his immortality". The death of nature and environmental loss is symbolic of the loss of feminine identity. (Adnan 1993: 17)

Unfortunately, the disastrous ecological state of the Sainte-Victoire Mountain disappoints her, and she sees it as a reflection of the general destruction of nature. Adnan writes that it is impossible to imagine a nature that could be immense and virginal, and since this space is filled up, our imagination turns toward an idea of the universe, of the cosmos. The dichotomy between city and nature is similar to the dichotomy between man and woman. This contrast is disappearing as we are moving again, and perhaps unhappily, towards unity: the cosmos and androgyny, for humans. The notion of place is replacing the idea of nature. The notion of the human person is replacing the masculinefeminine couple (ibid. 16-17).

In the seventh letter located at Beirut, Adnan returns to the idea of nature as a savior. She links woman and the sea, saying "If it weren't for the sea, Beirut would not have survived its devastation" (ibid. 80).

Adnan's commentary on nature and culture parallels that of the writer and philosopher Rousseau, who states that the development of culture and technical progress brings with it the disappearance of an essence of life. For Rousseau, the price of progression has been man's loss of the possibility or returning to a simple way of life in contact with nature. "Nature for Rousseau is becoming nothing but a barely audible voice at the heart of our societies, he has made himself its incarnation" (Tunney et al. 2016: Introduction). 
Representation of Places in Etel Adnan's In the Heart of the Heart of Another Country

\section{Symbolic Representation of Mountains in the Painting and Writing of Adnan}

Mountains often symbolically return in both the writings and paintings of Adnan. Traditionally mountains in A Dictionary of Symbols are symbolic of an "idea of meditation, spiritual elevation". (Cirlot 1971: 221) In In the Heart of the Heart of Another Country, - when referring to her homeland - Adnan talks about a house on the Barouk mountain, as well as the forests and the valleys of her youth in Lebanon. (Adnan, 2005: 84) Adnan is strongly attached to the mountains of her youth.

The feelings, metaphors and symbols mentioned surrounding the Mountain of Sainte-Victoire often symbolically recur in the writing and art of Adnan, as she references works by Cézanne, Picasso and others, following their paths to the exact locations where these artists took their inspiration from. In fact, the Sainte-Victoire Mountain is the subject of a famous work of Cézanne, and the reason for her travels there. Thus, in the book Of Cities \& Women (Letters to Fawwaz), this second letter in Aix-en-Provence continues with a, “[...] temptation created by a poster for a Cézanne exhibition on Sainte-Victoire: paintings and watercolors of the Mountain..." (Adnan 1993: 14). This is reminiscent of the first letter, when she travels to Barcelona to see the works of Picasso (making “The Picasso Museum” a focal point of her visit to Barcelona) (Adnan 1993: 6-7). In her own mountain paintings, her strong sense and use of color reflect the energy she feels in them. Unlike Cézanne, however, she does not repeat the same mountain myriads of times. Instead, she paints many mountains in various places wherever she roams. Her color palate is consequently highly inspired by these impressionist painters. (Adnan 2015: 30)

\section{The Sea and Oceans as Symbols of Death and Rebirth}

The sea has always been a prominent feature in both the writing and artwork of Adnan, from her beginnings until her latest works. A Dictionary of Symbols identifies oceans - according to Piobb, the Graeco-Roman conception of the ocean - as "dynamic forces and transitional states between the stable and the formless [...] a symbol of universal life, [...] a symbol of women or the mother." (Cirlot 1971: 241-242). Adnan tends to describe them as feminine entities with motherly qualities. For her, the sea, in the book "Sea and Fog", is a reflection of the feminine and a pool of memories, "Water on water reverberates memory's mechanism" (Adnan 2012: 3). Grammatically in Arabic, the term for the sea is masculine, however, poetically the author would like to refer to it as feminine. 
"They asked: is the sea a woman? I said yes." (Ibid. 21) Here Adnan ties the notions of nature and women together, linking them intrinsically and making it difficult to separate discussions on one from the other.

In the third chapter of In the Heart of the Heart of another Country, although the places keep changing, the ocean is always present, along with the sound it makes: "Oceans are the kind of place I would inhabit" (Adnan 2005: 47). Adnan constantly recalls her passion for the sea, presenting it symbolically through personification as well as allegory. Despite this, the only thing that remains constant as she moves around the world for work and study is "[...] particular lands and of its seas. I will disappear in an absolute sense if and only when they disappear" (ibid. 68).

In the book Of Cities \& Women (Letters to Fawwaz), the sea is like a rebirth for Adnan, who sees her return to the Mediterranean as a breaking out the tunnel that life in Paris and California had become (Adnan 1993: 38). This notion of the sea holds a similarity to the book by Khalil Gibran ${ }^{13}$, The Prophet, published in 1923, where he states on the opening page: "The sea that calls all things unto her calls me, I must embark" (Khalil 2018). For Gibran, the sea is like a giant uterus that will bring a purifying rebirth ${ }^{14}$. In contrast, Adan's sea is unable to help her in the way that Gibran's sea carries the prophet to a better life. In OfCities and Women, Adnan remembers how when she was a child, the sea meant everything to her. Now, after the atrocities of the war, she looks at the sea with different eyes, asking "for help" (Adnan 1993: 38) for her homeland. The sea represents a savior, a mother figure providing a constant source of support, stability and connection. Even in Barcelona, the sea from the terrace

13 Gibran Khalil Gibran, usually referred to in English as Kahlil Gibran, was a LebaneseAmerican writer, poet, visual artist and philosopher.

14 Boulos Tauk, in his Arab book شخصيّة جبر ان في أبعادها التكونيَّة و الحياتيَّة published the first time in French as La personnalité de Gubran dans ses dimensions constitutives et existentielles in 1984, - studies the various books of Gibran Khalil Gibran - among which is The Prophet - investigating the symbolic and cosmic origins of the names chosen in these books and their symbolism. According to Boulos Tauk, this symbolism in The Prophet (written in English) is a "collection of secrets"...; examples include, “"the temple" in the "Orphalese" square where "Almustafa" had given his speech on the steps, and "the ship," which had brought him from Orphalese..."”." "But the ship is the etheric body in the world of the "third level" III plan, and this body is no other than a means of transport - a mediator, across the water - fundamental - the cosmic motherhood (the sea) versus the island, a symbol of the home of the soul, happy in the eternity of infinity. The boat is the cradle, the rebirth, shaken upon the waters of the cosmic uterus. And it is the sarcophagus of crossing, the vehicle of death, shaken upon the shoulders of whoever moves it. The bed and the sarcophagus are one. And they are absence for the presence, and death for birth."” (Tauk 2000: 650-651) (Translation from Arabic by the author of the paper.) 
Representation of Places in Etel Adnan's In the Heart of the Heart of Another Country

connects her to her birthplace, reminding her of Beirut "it was the war, without death" (ibid. 11).

\section{Women of Various Cities}

Adnan's extensive travels in Europe have made her more aware of issues concerning women worldwide. She addresses them thematically and metaphorically, confronting their conditions in every place she travels, and comparing them with the women in her homeland. In Of Cities of Women (Letters to Fawwaz), Adnan firmly defends the rights of women in different cities. For the purposes of underlining the representation of mind maps created by the notion of women in Adnan's writings, this section will focus on the images of women throughout the letters in Of Cities and of Women.

Through the nine letters of the book, Of Cities and Women (Letters to Fawwaz), Etel Adnan takes the reader on a journey to discover what it is to be a woman in different contexts, reflecting on how the environment, culture, and people shape and define women's bodies, minds and liberties. As a nomadic writer, Adnan is free to observe and comment upon the state of women in each location, and also to criticize the lack of equality and civil rights, sometimes hidden beneath layers of so-called civility.

\section{Barcelona and Marrakesh}

In the first letter of the book, Of Cities \& Women (Letters to Fawwaz), Adnan goes to Barcelona (Adnan 1993: 1). She finds that, "the women of this city are free, which is to say that they appear to have control over their bodies and their movements" (ibid. 2). She believes that Arabic women form a society of their own and have been kept far from public eyes for a long time. She remembers that women in Marrakesh were not so free; "their social status much more than they carry their 'soul'” (ibid. 3). The author's nomadism opens her to different ways of thinking. Consequently, she wants to liberate all women and allow them to have a voice.

Contrastingly, the women in Barcelona remind her that they are not an exception, but rather playing an active part at a precise moment in time and space (ibid.). This is very different from the more oppressive regimes she had encountered elsewhere. Here, "freedom is a state of mind" that knows no gender. She references the book Ferdaous, by Nawal Saadawi which speaks 
about a prostitute who was "[...] like the great figures of History, who chose death rather than relinquish their interior freedom" (ibid. 8).

As she walks along the port, she arrives at a red-light district. Here is a clear example of Foucault where the red-light district represents a heterotopia - a place within another with its own set of rules, which highlights an aspect of the wider society without really being "part" of it. Although she states that prostitution has always seemed to have had a sacred, obsessive quality to it, the sight of a young, naked prostitute in Barcelona, who apparently had lost her senses and was acting like a wild monkey, "[...] put an end to all the illusions [...] as to the logic one could bring to the questions I'm asking myself now" (ibid. 12-13). There is no longer anything sacred in her view - only despair.

Although the women in Barcelona seem to be liberated, the situation of this prostitute demonstrates how even Western culture has not completely emancipated women from their traditional cultural roles.

\section{Greece and Beirut and the Technology of Tourism}

The third letter of OfCities \& Women (Letters to Fawwaz) is written in Skopelos, Greece. Adnan is extremely critical of what she describes as the "technology of tourism", which she believes has destroyed the island. "It shows in the character of the people. There's brutality in the air. A lot of brutality" (Adnan 1993: 32). One example of a human striving for a better economic situation is Alessandra, a local girl who does housework. Adnan notices that she embodies a strength typical of women like her who have had to fight their way to a better life - those who have always had to strive to achieve something of their own while never losing their dignity (ibid. 35). Her thoughts move to the Greek gods as she compares contemporary society to ancient Greece (ibid. 36).

By comparing the Arab world with that of Greek society, she underlines that, "When a woman is denied the right to drive a car over the thousands of miles of the former Arabic Felix or [...] greet her neighbor without risking her life, it is obvious that he world presents itself to her differently" (ibid. 37).

She continues on this topic stating that, "Women's liberation is a function of the liberties granted by the societies in which they live, and no gain is definitive [...] It is a civil war - the battle is chaotic and constantly shifting: in the bedroom, the street, the office, the salons" (ibid. 37). While every country or location faces the struggle in a different way, she believes the argument is spherical rather than linear in all of them. Adnan puts man and woman on the same level, commenting that rather than a question of gender, freedom of rights is a question concerning the definition of the human species as a whole (ibid. 37). 
Representation of Places in Etel Adnan's In the Heart of the Heart of Another Country

Moving on to Athens, she visits Byzantine churches and the Kaisariani Monastery, stopping in front of the fascinatingly beautiful fresco of the "Virgin known as the Evangelistria". This fresco is a pure example of everything "feminine" to her. It incorporates the strength bestowed "by the goddess of Babylon" (ibid. 44). The Evangelistria is a symbol of love and wisdom. The author is so taken by the vision of this painting that she finds it hard to move away.

\section{Amsterdam}

In the fifth letter, written in Amsterdam, Adnan continues her letter to Fawwaz beginning with a fond memory - that of her "mother's birth (and that of the Day for the Dead in Holland)" (ibid. 57). The paradoxical juxtaposition of birth and death underlines the contrasting realities of women's lives as they are constantly waiting to live.

While later watching an opera, she begins to analyze the role of Penelope. Penelope represents the role of women through the ages. Women are made to wait; to get married, to have children, to cook, to be kissed, rejected and forgotten. She waits for love, vengeance, oblivion, and eventually, death (ibid. 58-59).

During a visit to her friend Yanny she discovers how some women, "[...] are carefully arranged in the display windows of these shop dormitories; they display themselves in the atrocious lighting as straightforwardly as merchandise". Yanny explains that these women come from many different backgrounds and that some earn money, while others are treated badly and even murdered. All of them are victims of "drugs and violence" (ibid. 60).

Adnan cannot accept that the role of women can be diminished to mere passive objects to be used or sold. While Western cities seem to hold equality for women, they also hide a cruel reality of the lives of many women living there.

\section{Rome and Beirut}

The last two letters, eight and nine, are written in Rome, and in Beirut. In the eighth letter, for the first time, Adnan describes a city (Rome) as positive and the women there as radiant and confident (ibid. 96). She describes her deep love of the city through many images; opera is its natural birth child, its people exude sunshine in their warmth and she is finally happy. However, the history 
of the city is less important to her than its ability to fuel her beliefs and ideas about women and places. "Rome could help me to define my own thoughts. We need to find the right geography for our revelations" (ibid. 93).

Despite Rome's historical treatment of women throughout the Severus Dynasty and the Renaissance, in her eyes it is the place where women can assert themselves freely. By contrast, the denial of women's equality in the Mediterranean area has forced women to fight for their rights and has led them to define themselves in relation to their refusal of their status. However, Adnan does not see this fight as enough (ibid. 96).

In a poetic description, Adnan refers to Italy as silence - the silence of night, love, and expectancy - the silence of experiences. Silence is simple yet profound, and Adnan reflects on the fact that experiences - like silence - are the simple catalysts to knowledge and understanding which go beyond what any theory could teach (ibid. 98).

\section{Beirut: Women and War, Death and Rebirth}

The seventh letter starts with the author's return to her homeland. An immediate sense of home invades her. In Lebanon, the memory of war had melted into the eyes of the people. The result of fifteen years of war is everywhere in the eyes of the homeless children, and the voice of the desperate woman asking for help (Adnan 1993: 72-73).

Speaking about the role of women in the war, Adnan describes women in Beirut as memory keepers. Beirut, “[...] allows its wounds to show wherever it is unable to conceal them, without recrimination, without tears, without begging". She is struck by the dignity that the people show - the most noble of virtues have survived the war (ibid. 75). Women have not lost themselves during the war; they continue to live their everyday lives (ibid. 78).

Adnan is not pessimistic in her view of women or the city of Beirut. Women embody life beyond their mortal state and the city of Beirut is also a lot more than the rubble left behind in the aftermath of a war (ibid. 114).

\section{The Notions of War and Wires}

The third part of Adnan's trilogy "Nature-Woman and War" becomes apparent through the author's repetitive use of imagery involving wires. The image is used frequently in both In the Heart of the Heart of Another Country and Of Cities and Women, and underlines her constant referral to war in every place she visits. 
Representation of Places in Etel Adnan's In the Heart of the Heart of Another Country

In the first book, In the Heart of the Heart of Another Country, for the author, "the thread of this century is made of wire" (Adnan 2005: 9). Wires disturb Adnan's vision of paradise (ibid. 22). The war in Beirut has destroyed all the trees for the birds, and the trees have been replaced by sterile wire poles. There is a sense of exile and foreboding. When the author first saw barbed wires in California, she immediately associated them with a sense of war and misery. Only in small moments of freedom is she able to see a more positive image of birds sitting on the wire to rest (ibid. 28). But usually wires are symbols of doom which are meant to protect us but lead instead to death, like "the bird dead from lack of water" (ibid. 40).

In the last chapter "To Be in the Time of War", although far from the conflict, Adnan is constantly haunted by its shadow, which permeates all hours of her day. Nothing can console her or give her peace, and she constantly thinks of her homeland and the suffering of the people there. No-one around her seems either to understand or to care. She feels as though she is a prisoner in her home. She can only "look at the narrow and long road that leads the world to the slaughterhouse" (ibid. 116).

In the second book Of Cities and Women (Letters to Fawwaz), Adnan is led to a series of questions which refer back to the chapter, "To be in the time of war" in the previous book. With the use of infinitives, "to live", "to share", "to eat", she questions the existence of the soul. Adnan writes "we need to drink and vomit, to vomit an overused soul to make room for the possibility of a new one, something which we are far from being sure to get” (Adnan 1993: 55).

\section{Conclusion}

The mind maps (or conceptual maps) outlined by Adnan are similar to digital maps of today that one finds on the Internet - fleeting and in constant evolution. While these maps are not literal, in that they are not physically drawn with vectors and points, Adnan draws an itinerary using the juxtaposition of places and themes, which the reader can use to create a map unique to his or her interpretation, by intertwining notions of nature, women, and war and fixing them simultaneously to locations in the present and places from Adnan's memories. The reader becomes the writer and creator of conceptual maps, as Adnan leads them on a journey to defend women's freedom through observations and criticisms of the situations of women.

In her psychogeographical wanderings Adnan not only discovers new places, but also discovers a new definition of self. Her literature and art are an active expression of her very self, which is created and recreated in each 
location. Although the places remain the same, they change as the years pass; people come and go, and, as she returns, she discovers that only her memories remain, while the places themselves are in constant transformation. This mirror of herself - past, present and in evolution - intertwines her locations with her emotions and experiences.

Each of Adnan's metaphors (such as the sea and the mountains, wires and windows) allows for multiple journeys by the reader, who can choose to follow her down the path of exploring themes, such as women's rights, observing the similarities and changes to the natural environment, or reflecting on how war permeates and transforms the lives of those who experience it. Adnan's unique perspective transforms her writing into a "psychogeographical literary" map, and no matter which trail the reader follows, they will be led to a unique vision of each space created by her.

\author{
Laure Zarif Keyrouz \\ laurekeyrouzarts@gmail.com \\ Nervesa della Battaglia \\ Via Del Solstizio 62 \\ 31040, (TV) \\ ITALIA / ITALY
}

\title{
References
}

Adnan, E. 1993. Of Cities \& Women (Letters to Fawwaz). Sausalito, CA: The PostApollo Press.

Adnan, E. 1996. To Write in a Foreign Language. - Electronic Poetry Review, https:// qcpages.qc.cuny.edu/cmal/faculty/alcalay/adnan2.pdf (02.06.2019).

Adnan, E. 2005. In the Heart of the Heart of Another Country. San Francisco: City Lights Books.

Adnan, E. 2012. Sea and Fog. Callicoon, NY: Nightboat Books.

Adnan, E. 2015. La joie de vivre. [Exhibition catalogue.] Zürich: Museum Haus Konstruktiv Selnaustrasse.

Bonniot-Mirloup, A. 2016. Tourism and Writer's Houses, in between Places and Literature. Trans. M. Jackson. - Via: Tourism Review, 9. https://doi.org/10.4000/ viatourism. 808

Chartier, R. 2014. The Meaning of Representation. Translated by M. C. Behrent. Books and Ideas, https://booksandideas.net/The-Meaning-of-Representation. html (02.06.2019).

Cirlot, J. E. 1971. A Dictionary of Symbols. Second edition. London: Routledge.

Debord, G. 1955. Introduction to a Critique of Urban Geography. Trans. Ken Knabb. http://www.bopsecrets.org/SI/urbgeog.htm (05.11.2019). 
Representation of Places in Etel Adnan's In the Heart of the Heart of Another Country

Debord, G. 1958. Definitions. Transl. K. Knabb. - Internationale Situationniste, 1 (June), https://www.cddc.vt.edu/sionline/si/definitions.html (24.06.2020).

Foucault, M. 1984. Des Espaces Autres. Trans. Jay Miskowice. - Architecture Mouvement Continuité, http://web.mit.edu/allanmc/www/foucault1.pdf (03.06. 2018).

Hess-Lüttich E. W. B. 2012. Spatial Turn: On the Concept of Space in Cultural Geography and Literary Theory. - Journal for Theoretical Cartography, 5, 1, http:// ojs.meta-carto-semiotics.org/index.php/mcs/article/view/21

Jeremiah, M. A. 2000. The Use of Place in Writing and Literature. - Language Arts Journal of Michigan, 16, 2, Article 7. https://doi.org/10.9707/2168-149X.1352

Juvan, M. 2015. From Spatial Turn to GIS-Mapping of Literary Cultures. - European Review, 23, 1, 81-96. https://doi.org/10.1017/S1062798714000568

Khalil, G. 2018. The Prophet. London: Global Grey, https://www.globalgreyebooks. com/prophet-ebook.html (12.11.2019).

Rousseaux, F., Thouvenin, I. 2009. Exploring Informed Virtual Sites through Michel Foucault's Heterotopias. - International Journal of Humanities and Arts Computing, 3, 175-191. https://doi.org/10.3366/ijhac.2009.0015

Shaw, J., Van Tijen, T. 1991. Literary Psychogeography. - http://imaginarymuseum.org/ LPG/Litpsy91.htm (07.06.2019).

Škulj, J. 2004. Literature and Space: Textual, Artistic and Cultural Spaces of Transgressiveness. - Primerjalna Književnost, 27, 21-37. https://ojs-gr.zrc-sazu.si/ primerjalna_knjizevnost/article/view/5102

Tauk, B. 1984. La personnalité de Gubran dans ses dimensions constitutives et existentielles. PhD thesis. Université de Strasbourg.

Travis, C. 2015. Visual Geo-Literary and Historical Analysis, Tweetflickrtubing, and James Joyce's Ulysses (1922). - Annals of the Association of American Geographers, 105, 5. https://doi.org/10.1080/00045608.2015.1054252

Tunney, A. D., Y. C. Zarka, eds. 2016. Rousseau, between Nature and Culture, Philosophy, Literature, and Politics. Berlin; Boston: Walter de Gruyter.

Vermeulen T. 2015. Space is the Place. - Frieze, 171, May, https://frieze.com/article/ space-place (03.06.2018).

Yales, R. 2015. Hoisting Anchor: Exploring the Interaction Between Time, Place, Space and Text in Early Modern American Travel Narratives Using Digital Technologies. MSc Dissertation, University College London.

Zarif Keyrouz, L. 2020. Mobility and Identity in the Art and Literature of Etel Adnan. - Dve domovini/Two homelands, 51, 133-150. https://doi.org/10.3986/ dd.2020.1.08 